\title{
The Performative Power of Narrative in Goliarda Sapienza's Lettera aperta, L'arte della gioia and Io, Jean Gabin.
}

\author{
Alberica Bazzoni (University of Oxford)
}

Keywords: Goliarda Sapienza; voice; identity; auto-fiction; performative narrative; agency.

\begin{abstract}
:
This article investigates Goliarda Sapienza's distinctive use of narrative as 'performative', focusing on narrative voice and structures in three works: Lettera aperta, L'arte della gioia and Io, Jean Gabin. Overall, my analysis postulates an evolution from a performative and deeply unstable narrating 'I' to a reinforced narrating voice and identity, that of an anarchist artist. In the analysis of narrative voice and structures, I refer to Adriana Cavarero's notions of voice and narration and Jean-Claude Coquet's reflections on body and language; I also employ Mark Turner's concept of 'blended space' and Peter Brooks's insights on plot and teleology. Sapienza's narrative incorporates the main instances of modernity and postmodernity in a highly disrupted and open narrative, but goes beyond it as it gives voice to a strong aspiration of freedom and a notion of performative identity still able produce agency and emancipation, which constitutes this author's significant originality.
\end{abstract}

\section{Introduction}

After a long period of oblivion, Sicilian writer Goliarda Sapienza (1924-1996) is now increasingly coming to be regarded as a major figure in twentieth century Italian literature, attracting both wide popular success and international critical attention. Against the resistance of major publishers, the success of Sapienza's works was supported by readers and independent publishers, who allowed her masterpiece L'arte della gioia to circulate and find in France, Germany and Spain its way to a wider readership. ${ }^{1}$ Since the posthumous Einaudi edition of L'arte della gioia in 2008, literary reviews, blogs, cultural events, readings and talks are multiplying, jointly with the re-issuing of previous works and the posthumous publication of new ones. ${ }^{2}$ Moreover, Sapienza's life and literary works have become a source of inspiration to other artists, sprouting into drama plays, performances, life writing and music. ${ }^{3}$ To these, must be added the growing number of literary reviews in several languages, boosted by the publication in the UK and the US of the English translation of L'arte della gioia in $2013 .{ }^{4}$

Sapienza's works are characterised by the centrality of autobiography and auto-fiction, and are closely informed by the experiences that marked her life - her atypical upbringing, 
the early encounter with socialist and feminist political commitment, her work in theatre and cinema, her troubled negotiation of gender identity and sexuality, depression, her experience of psychoanalysis, poverty and prison. Her narrative is situated half-way between experimentalism and legibility, as it blurs genre boundaries, intensely manipulates linguistic and narrative structures and expresses radical social criticism, but maintains nonetheless an affable attitude towards the readers, who are invited to participate in her search for identity and freedom. From a position of marginality and eccentricity, Sapienza gives voice to a radical and subversive aspiration of freedom and new, creative ways to conceive personal identity and human relationships. The act of narrating is entrusted with a fundamental function, consisting in the possibility for the narrator to create her own story and transform a concluded, suffered past into a chosen, active, and joyful space for action.

This article proposes to analyse the evolution of Sapienza's narrative by focusing on the qualification of the narrating voice and the narrative structures in three of her works: Lettera aperta, L'arte della gioia and Io, Jean Gabin, ${ }^{5}$ which represent distinctive and significant steps in such evolution. I define Sapienza's use of narrative as 'performative' in two correlated senses: first, narration is presented as a theatrical performance, miming the expression of life as it happens and with the text configured as oral speech, addressed to a physically present audience. Second, linked to the first one, narration is conceptualised as performative as it realises the narrator's own identity formation, which is thus configured as properly narrative. ${ }^{6}$ In analysing the act of narrating as a performative oral speech, I refer to the theory of voice - with its distinctive characteristics of relationality and corporeality elaborated by Adriana Cavarero in A più voci and her philosophy of narration developed in $T u$ che mi guardi, tu che mi racconti. ${ }^{7}$ I also draw from the interpretation of the relationship between body and language provided by French linguist Jean-Claude Coquet, while in the analysis of narrative structures I employ Mark Turner's concept of 'blended space' and Peter Brooks's reflections on plot and teleology. ${ }^{8}$ Overall, my analysis postulates an evolution, from a performative and deeply unstable narrating 'I', prevailing in Lettera aperta, to a reinforced narrating voice, which achieves a certain degree of detachment from her past, in Io, Jean Gabin. The structure of the texts changes accordingly, from the loose assemblage of episodes and thoughts characterising Lettera aperta, to the - albeit minimal - plot developed in Io, Jean Gabin, passing through the fictional representation of a present in fieri and the plot without teleology of L'arte della goia. 


\section{Lettera aperta: Staging the Past, Voicing the Present}

\subsection{Disrupted Memories}

Lettera aperta, published in 1967, inaugurates Sapienza's literary endeavour. Narrated in the first person, it recounts the story of a double formation, of a young girl in Sicily and a mature woman in her forties in Rome. The narrator engages with the memories of her parental figures and her libertarian formation within fascist, catholic and deeply patriarchal Sicily. Episodes and figures mainly from her childhood, with some minor scenes belonging to other significant periods of her life, compose a multifaceted and fragmented portrait of a young girl's troubled upbringing, and of an adult woman's endeavour to free herself from the weight of an oppressive past.

The coincidence of protagonist's and author's name ascribes the work to the autobiographical genre, and the central theme of a young girl's upbringing recalls the structure of the Bildungsroman - or, more specifically, the 'romanzo del divenire', the definition used by Laura Fortini and Paola Bono (along the lines of the Bakhtinian novel of emergence) to emphasise the openness of the formative process. ${ }^{9}$ Within the literary genres of autobiography and novel of emergence, however, Lettera aperta presents a number of features that complicate and destabilise the genre structure, realising, in Anna Langiano's words, 'una forma-romanzo aperta e contaminata'. ${ }^{10}$ Having survived two suicide attempts and partially lost her memory due to electroconvulsive therapy, Sapienza embarks on a journey of self-reconstruction, revisiting her childhood in the attempt to recompose her disrupted memory. Accordingly, the narrative discourse is subject to intense fragmentation events are linked through analogical rather than chronological associations, and characters, voices and episodes are often confused or even obscure, as the narrator is caught in the middle of the process of recollecting her past. The work of a disrupted memory, with its incoherencies, gaps and analogical associations, is reproduced through the narrative discourse. ${ }^{11}$ As Langiano points out,

la scrittura di Goliarda Sapienza punta alla sistematica frantumazione dei livelli di senso: le gerarchie temporali vengono destabilizzate, la coerenza del rapporto tra causa ed effetto vanificato in nome della compresenza di tempi diversi e eventi apparentemente indipendenti l'uno dall'altro [...]. ${ }^{12}$ 


\subsection{A Twofold Narrating Voice}

In addition to the fragmentation of the narrative discourse, due to the isomorphism between disrupted memory and narration, Lettera aperta also features a doubling of the narrating voice. The adult narrator alternates with a child's voice, that of the young Goliarda in the late 20 s and early 30s in Catania. As Giuliana Ortu points out,

La voce recitante si alterna: è ovviamente sempre la Goliarda adulta che scrive, ma spesso è come se emergesse la bambina, delineata apparentemente senza mediazioni né analisi, con la registrazione in presa diretta di luci, suoni, luoghi e parole di allora. ${ }^{13}$

Similarly, both Anna Carta and Mariagiovanna Andrigo describe the narrator's participation in the episodes from her childhood as a 'rievocazione', thus stressing the element of representation of the child's perspective. ${ }^{14}$

Not only the perspective is twofold, but also the focus, since the present of the narrator alternates with recollections from childhood as the foregrounded topic of narration. The narrator of the story, with her own present troubles, her struggle to remember and survive, effectively constitutes the co-protagonist of the book. By telling the story of the progressive oppression she underwent as a child, the adult narrator seeks to undo it, retrieving an instinctive vitality and becoming the active subject of her own narrative.

The dynamic, pulsating connection established between the process of recollecting and the narrator's search for identity in Lettera aperta differs significantly from the stable relationship between present and past set in traditional forms of autobiography, such as in the works by Augustine, Rousseau, Goethe and Alfieri. In those works, the past is presented as concluded, detached from the present and exalted in its exemplarity. To borrow Cavarero's words, in traditional autobiographies 'il teorema sotteso è che esista in primo luogo un soggetto autocosciente il quale, mettendosi a scrivere la sua vita, traduce in parole la realtà sostanziale, precedente e indipendente dal testo, del proprio io' ${ }^{15}$ The traditional, rational subject uses narration to detach the present from the past:

Egli mette in atto 'il freddo distacco della narrazione' che trasforma 'i fatti naturali in qualcosa di trascorso da lunghissimo tempo.' Attraverso l'uso della memoria, distanzia le storie consegnandole alla dimensione del tempo che separa gli accadimenti passati dal presente del narratore. ${ }^{16}$ 
Conversely, in Lettera aperta the past is not concluded, but active on the present and actively interpreted by the present narrator who interacts with it. The act of remembering and narrating affects the past itself as this is dismantled and explored repeatedly, according to the evolving meaning it assumes in the present. Sapienza achieves such a mutual contamination of past and present through various narrative techniques. For example, the narrator comments on the effects of re-evoking certain episodes, and interacts with figures from her past as if they were present in the same spatio-temporal domain as hers. Furthermore, she constantly manipulates tenses and temporal and spatial deictics so as to blur the distinction between the adult and the child perspective: 'dovevo aver dormito molto [...] era domenica e avevo ancora il malditesta. Sicuramente ho anche i capelli bianchi. Devo andare a controllare'; 'La sera prima, finalmente, avevo visto "La Regina Cristina". [...] Ieri sera pioveva quando siamo usciti dal cinema' (LA, p. 57. My emphasis). The changes in tenses and deictics disrupt the cohesion and linearity of the events, blurring the line between the spatio-temporal coordinates of the narrator and those of the child, between present and past.

A striking example of the interaction between present and past, narration and story narrated, is represented by the episode of Anna 'la sediara', when Goliarda is abandoned by the artisan and waits for her sitting outside the shut door of her house. ${ }^{17}$ Anna's sudden departure deprives Goliarda of the training in manufacturing chairs that had given her a sense of fulfilment, and means to her the loss of 'un modo di essere utile all'umanità' (LA, p. 91), causing deep feelings of pain and distress. This episode, associated with a loss of identity, has its repercussions on the narrator as well, since she - the adult woman - is still in search for an identity she lost in front of Anna's shut door. Re-experiencing the child's own trouble Sapienza uses the verb 'risillabare' - the narrator waits like the child and, like the child, seeks to find her place in society, her 'utilità', her identity. The child's act of waiting on Anna's threshold is paralleled by the narrator's own suspension of narration, which results in a blank space on the page.

Ma Anna era andata via e non mi aveva neanche guardata. [...] Mi sedetti sulla soglia, sotto quella porta sbarrata, e aspettai fino a notte. Aspettai, ma sapevo che non sarebbe tornata. $[\ldots]$

Non dovevo parlarvi di Anna, lo sapevo, non dovevo risillabare quella domanda che mi feci: Perché non tornano i grandi? Non dovevo. Questa domanda mi costringe a sedere su quella soglia in attesa. [...] Scusatemi, ma visto che aspetto debbo lasciarvi per un po'. Non posso costringervi ad aspettare con me. Quando uno aspetta e piange, non è 
divertente né utile per gli altri e così, abbiate pazienza, se resto su questo gradino muta per qualche tempo, debbo aspettare, ma da sola.

[Blank space on the page]

...Devo tornare a quel gradino: solo tornando a quella soglia oggi, forse, potrò capire il senso di questa attesa, che, come tante altre cose, ci fanno subire i grandi.

[Blank space on the page]

Anche oggi, come ieri ho aspettato piangendo, seduta sulla soglia: stasera, ieri sera, tre sere fa, un anno? (LA, pp. 87-8)

The child's wait becomes a pause in the process of recollecting, and this hiatus in turn becomes a blank space on the page and invites the reader to participate in the time of the story narrated as well as in that of narration. Through writing, the time of the pause translates into the material space on the page, generating a short-circuit between space of the story narrated, narrative discourse and material, extra-textual reality.

The visual technique of a blank space on the page is one of the numerous characteristics, together for example with the regular appeals to the reader and the non-linear, digressive structure of narration, that connect Lettera aperta with Laurence Sterne's Tristram Shandy. ${ }^{18}$ Sterne's influence on Lettera aperta is indeed pervasive, and would require specific enquiry, but it is significant to point out here that Tristram Shandy is mentioned twice in the novel, with explicit references to the materiality of the book ('la mia stanza è un po' troppo umida, e così Tristram si è tutto appiccicato a questo libraccio, e per staccarlo lo dovrei squarciare da capo a fondo.' LA p. 30), and to the meta-narrative dialogue with the reader:

NOTA: [...] ho premesso un 'Si può non leggere' o, come avrebbe detto il nostro caro fedele amico Tristram Shandy:

\section{CHIUDETE LA PORTA ${ }^{19}$}

Mark Turner's concept of 'blended space' can provide a useful tool to understand Sapienza's manipulation of narrative in the passage above, in particular as concerns her dialogue with the readers. In The Literary Mind, Turner provides a cognitive analysis of the fundamental mechanisms of thought, which he identifies as essentially narrative. According to Turner's cognitive theory, human thought relies on the centrality of stories, which bring together and combine different conceptual spaces to produce a coherent unit. He applies his theory of 
thought to the analysis of literary texts, pointing out the ability of stories to creatively 'blend' separate conceptual spaces. In particular, Turner analysis the interaction between story narrated and narration. He proposes to situate this kind of interaction (typically in the case of a myse en abyme of the narrative discourse) in what he defines a 'blended space', a conceptual space separated both from that of the narrator and that of the characters. In this third conceptual space, elements from the two domains are blended, realising a contact and interaction that would be impossible in either domain. In Turner's words, 'in the blend, the narrator, the readers, and the characters can inhabit one world'. ${ }^{20}$

While the practice of blending story narrated and narration is widespread in literary texts, it is normally used in the direction of the narrator's interference with the story narrated, so that he or she acquires 'special powers' in the story narrated: the narrator can move freely in time and space, read the characters' minds, etc. ${ }^{21}$ Sapienza effects a conflation between narration and story narrated also in a different, unexpected manner. In Lettera aperta, indeed, not only the narrator affects the story narrated with her 'special powers', but also and more importantly the story narrated affects the narrator. As we have seen, it is the child's wait that causes the narrator to pause, and asks the reader to wait with them, lingering on the blank space on the page.

\subsection{The Readers as an Audience, the Text as an Oral Performance}

Another 'blended space' is the one shared by the narrator with the readers, who are repeatedly evoked as an interlocutor present in the same space as the narrator's. The readers are called to perform an active role in the discourse, since the narrator relies on their reaction to orient her act of remembering and narrating. Let us see how this works in the text. In the incipit of the text, Dina, the narrator's housekeeper, comments negatively on a decorative object on a shelf. Her comment, 'Quanto è brutto!' (LA, p. 16) triggers the narrator's journey into her past, configured as an act of 'tidying up' her memories paralleled to the physical act of tidying up the room - getting rid of ugly objects, keeping good memories. Dina represents the textual figure of the reader, whose judgment orients the narrator in her selecting and sorting endeavour. It is important here to note also that the act of tidying up the room is not a metaphor for putting order in memories, since memories are actually, physically attached to the objects in the room. Again, narration and the space of the narrator conflate.

While in the incipit Dina provides a textual figure for the reader, inhabiting the same space as the narrator's, straight after the episode of the 'ugly object' Sapienza leaves behind 
any textual mediation and directly addresses the readers, who are invited to participate actively in the process of tidying up:

Scusate ancora, ma ho bisogno di voi per essere in grado di sbarazzarmi di tutte le cose brutte che ci sono qui dentro. Parlando, dalla reazione di chi ascolta, puoi capire cosa va tenuto e cosa buttato. Ho bisogno di voi per liberarmi di tutte le cose brutte che affollano questa stanza. (LA, p. 16)

In the text, the readers are represented as actually performing this role, since the narrator is able to perceive their reactions to the text as she narrates: "Vedo dai vostri visi che questa morte vi ha affaticati' (LA, p. 36). Clearly, the space where such a communication between readers and narrator can take place, overcoming temporal and spatial impossibility, is properly a blended space.

What type of space is, then, the blended space created by Sapienza, where story narrated, narration and readers can communicate and influence each other? As the whole setting of the text indicates, such a blended space is configured as a theatrical space. And indeed, Sapienza's experience as an actress, first in theatre and later in cinema, leaves a significant trace on her writing. Narration is an oral performance, which memory after memory and through the dialogue with the readers (re)creates the narrator's own identity. The act of narrating is qualified throughout the text as oral speech, pronounced in front of an audience - which Langiano defines 'lettorespettatore'. ${ }^{22}$ As Castagné remarks, 'qui lo scritto è specificamente parola'. ${ }^{23}$ Narration is a 'sproloquio' (LA, p. 31), to think and remember is 'parlare, comunicare', to read is 'ascoltare' (p. 53) and to end narration is 'tacere' (p. 159).

To qualify narration as irreducibly vocal entails to attribute to intersubjective communication a crucial role, as we have seen in the narrator's repeated appeals to the readers. Cavarero notes: 'Nell'ambito etimologico della vox latina, il primo significato di vocare è chiamare, invocare. Prima ancora di farsi parola, la voce è un'invocazione rivolta all'altro e fiduciosa in un orecchio che l'accoglie.' ${ }^{24}$ Through her voice, the narrator of Lettera aperta imitates a physical presence on a stage, shared with the audience. In doing so, she brings her physical existence into the text, refusing to dissociate language from the body and thought from communication. Sapienza's literary operation recalls Cavarero's argument in favour of the voice - physical and uniquely personal voice - as opposed to abstract, universal and ultimately disembodied representations of thought and language. As the philosopher puts it, 'al contrario del pensiero che tende ad abitare nel mondo immateriale 
delle idee, il discorso è sempre una questione di corpi, necessariamente sanguigni e pulsanti, desideranti e scatenati'. ${ }^{25}$ Similarly, according to Jean-Claude Coquet, a French linguist of phenomenological orientation, the linguistic ' $\mathrm{I}$ ' is always and primarily a body, and written language necessarily bears traces of the corporeal dimension of oral speech: 'Il corpo partecipa tanto alla lettura quanto alla scrittura. [...] Dunque la scrittura non è dissociabile dalla voce.' 26

\subsection{The Enunciation of the Self in the Present}

Cavarero notes, 'il tempo e il luogo della narrazione non sono sempre e necessariamente postumi. Imitando il discorso diretto, la mimesis colloca infatti il racconto dell'eroe nel tempo e nel luogo del suo accadere'. ${ }^{27}$ The narrator of Lettera aperta, in place of remembering a concluded and detached past, through her speech enunciates herself in the present, miming her physical presence. By subtracting her biography from the concluded and detached dimension of the past, 'ciò che è già stato fatto e non può essere disfatto', ${ }^{28}$ and re-presenting it into her discourse, Sapienza can thus exert her agency on her own story, appropriating it. Narrative enables the narrator to undo the oppressive path she underwent as a child and liberate herself, marking her own biography as a chosen space and not an imposed destiny. She becomes, in other words, the actor of her own story, and indeed theatre, 'quest'estratto di vita', was created by humans 'per tenerla in pugno almeno per un paio d'ore' (LA, p. 31). Writing is thus, for Sapienza, a way to exert her own agency, to turn passivity into active construction and gain control of her life. Through writing, she accomplishes an autogenesis and creates herself as a narrator, similarly to what Sibilla Aleramo realises in Una donna. ${ }^{29}$ Significantly, the appropriation of life through a performance of the self is thematized in the text with a specific reference to acting:

Oggi, 10 maggio 1965, compio 41 anni ed ho quasi finito questo mio libro che se riuscirò ad impararlo a memoria - io non so improvvisare: ho fatto l'attrice e devo, per parlare, avere un copione - sarà il mio parlare a voi. Oggi rinasco o forse nasco per la prima volta. Ho un anno, solo un anno.' (LA, p. 146)

Clearly, there lies a crucial contradiction here, for the operation of appropriating and representing the past as a chosen story performed by the actor-narrator is and remains, after all, fictional: 'la messa-in-scena è ovviamente una finzione, una rappresentazione: un racconto, in 
altre parole. ${ }^{30}$ However, the fictional performance of the self participates in a deeper, nonfictional reality, since it expresses the very real constitution of identity through narration.

Carta, pointing out the affinity between the use of narration in Lettera aperta and Cavarero's philosophy of narrative, notes that 'l'autobiografismo della Sapienza contiene una riflessione sulla natura, sulle motivazioni profonde, sullo statuto originario della narrazione'. ${ }^{31}$ In Lettera aperta, Sapienza exhibits the process through which the self constructs its own story, a process that, in Cavarero's perspective, is intrinsically narrative, for 'nella memoria narrante il sé ha la propria casa'. ${ }^{32}$ Similarly, Turner attributes a primary and fundamental cognitive role to the human faculty of organising reality into stories, for narration is understood as the founding structure of thought and language. ${ }^{33}$ From a sociological perspective, Margaret Somers finds in 'conceptual narrativity' and the 'ontological dimension of narrative' the key notions to understanding the processes of identity formation. ${ }^{34}$ Where the characterisation of the text as oral performance and the mimesis of a present in fieri have a component of fiction, the use of narration to recompose memories and reconstruct the self are an extremely powerful tool whose very real effects on the narrator herself are represented in Lettera aperta.

The notion of performative narrative, read with the support of Cavarero's reflections on the voice and narration, and Coquet's notion of the permanence of the body into language, helps us make sense of the contradiction, in Sapienza's narrative, between the aspiration to establish a bodily foundation for identity, as opposed to a self that is always the result of a linguistic, textual operation. Sapienza wrote: 'Per me quella che chiamiamo vita, prende consistenza solo se riesco a tradurla in scrittura'; ${ }^{35}$ Charlotte Ross points out this twofold motor in Sapienza's writing:

Sapienza spiega che il suo senso di sé è costruito in modo discorsivo e mediato [...]. Per poter assumere consistenza, le sue esperienze devono essere paradossalmente incanalate attraverso il testo, anche se Sapienza insiste più volte anche sul carattere corporeo della nostra condizione ontologica. ${ }^{36}$

The contradiction between textual and bodily foundation of identity is overcome by the characterisation of text as itself constituted and inhabited by the body, and the very process of identity formation as narrative. Configured as a performative speech in which the narrator, like an actor, performs her own story, the text coincides with the physical act of narrating, which has a very real, material effect on the narrator herself. Autobiographical narration in 
Lettera aperta then retains a relationship with extra-textual reality, inasmuch as it enables the narrator to survive and appropriate her own past. As Maria Arena puts it, 'la scrittura diviene la sua cura, il luogo dove rinasce il suo desiderio'. ${ }^{37}$ And it is worth mentioning here that in $I l$ filo di mezzogiorno, published in 1969, Sapienza continues her auto-fictional journey by recounting her own psychanalytical experience, thus explicitly merging therapy, identity formation and writing. ${ }^{38}$ To use Sapienza's own words from L'arte della gioia, 'chi nasce con il talento di raccontare è anche uno che guarisce' (p. 489). Indeed, the conclusive chapter of Lettera aperta ends on the narrator's demand for the freedom to play with her own body, that source of vitality with which, thanks to the narration of her own story, she has regained contact. Narration does not only represent the formation of the self, but realises it.

\section{L'arte della gioia: Living and Narrating, Living as Narrating}

\subsection{Mimesis of the Present in Action}

In Lettera aperta the narrator, by narrating her own story, performs a process of self formation, and this operation, as we have seen, retains an element of fiction, although a fiction with very real and material effects. In the passage to L'arte della gioia, Sapienza gives up the illusion of autobiography to embrace declared fiction, in which the narrator can actually be the creator, rather than the actor, of a story. Narrated in the first person, L'arte della gioia tells the story of Modesta, who was born in 1900 to a very poor family in Sicily. Through a series of adventurous circumstances and a relentless struggle for freedom, she manages to attain reaches, love and independence, always pursuing the 'joy' of life.

While in Lettera aperta Sapienza stated the impossibility of truth in autobiography 'credo proprio che questo mio sforzo per non morire soffocata nel disordine, sarà una bella sfilza di bugie' (LA, p. 16) -, in the incipit of L'arte della gioia Modesta, the protagonist, affirms: 'Lasciamo questo mio primo ricordo così com'è: non mi va di fare supposizioni o d'inventare. Voglio dirvi quello che è stato senza alterare niente' (AG, p. 5). Once the element of fiction is assumed as the explicit frame of the text, within the fictional world the narrator can, indeed, tell the truth, for she is the actual author and source of it.

We can note how Sapienza follows a path that is diametrically opposed to Natalia Ginzburg's, who gradually approached autobiography as a liberating possibility to talk about her own reality, after an intense literary production all centred on fictional stories. In the 'Avvertenza' that precedes Lessico famigliare (1963), Ginzburg states a complete adherence 
to reality: 'Luoghi, fatti, persone sono, in questo libro, reali. Non ho inventato niente. ${ }^{39}$ At the same time, she warns the reader about the faltering and selective feature of memory, and suggests that the work should be read like a novel. From different perspectives - Sapienza embraces exhibited fiction, while Ginzburg moves from fiction to autobiography - both writers express the limits of the possibility for autobiography to tell the truth. As Farnetti writes,

Rendere narrabile la vita così com'è e come la si è vissuta non è possibile. [...] Non si discute più, dunque, in termini di sovrapposizione fra vissuto e scrittura, ma piuttosto di trasposizione dal vissuto all'inventato, si tiene conto dello scarto d'invenzione che ogni scrittura produce, e su quello scarto si lavora. ${ }^{40}$

Within the passage from autobiography to overt fiction in L'arte della gioia, we notice nonetheless a substantial continuity with Lettera aperta as concerns the configuration of the narrating voice and her position with respect to the story narrated. L'arte della gioia is a fictional autobiography that adopts an internal focalisation, as the narrating voice belongs to the protagonist herself. The point of view is strictly limited to her experience, and she has no access to the other characters' thoughts nor to events beyond her personal knowledge. The story is told mainly in the past tense, thus suggesting a traditional narrative structure in which a character recollects his/her life and composes it into a meaningful story. The narrator is supposed to speak from a position located at the end of the story, from which she would look back at past events. However, the location of the narrating voice is not stable, as there is a constant fluctuation between present and past tense, which, as in Lettera aperta, influences the structure of the plot and the relationship between story narrated and narrative discourse. Indeed, from the very beginning the present tense alternates with the past, something which characterises the whole work: 'Ed eccovi me a quattro, cinque anni in uno spazio fangoso che trascino un pezzo di legno immenso. [...] Voglio dirvi quello che è stato senza alterare niente' (AG, p. 5. My emphasis).

In addition to the pervasive use of the present in place of the past tense, in the first part of the novel the metaphorical references are limited to the world known by Modesta as a child and adolescent. The mountains are 'nere come i capelli della mamma' and 'azzurre come il vestito della domenica' (AG, p. 6). Not only the metaphors but the whole system of perceptions is that of the child, who narrates from her limited and naive perspective. The almost total absence of prolepses further reduces the distance between the narrator and the 
character as the former does not tell more than what the latter is able to know. Modesta's adult narrating voice presents herself as strongly sympathetic with the character who is living and not recollecting her experiences, situating herself in the middle of, rather than after, the events.

In the last part of the novel there is an overt reference to the act of writing memories, accompanied by a reference to notes Modesta would have written down in the past, which suggest the form of re-elaboration of diaries. The statement is followed by a sudden return to the present tense, which marks a time where the character, not the narrator, resides:

E come in quel lontano 1945 il silenzio calò sui brevi appunti della mia vita, ammutolisco di nuovo ora che scrivo, e tremo cercando il nome di Jacopo fra le carte. Temo d'aver perduto la data del suo ritorno. L'attesa rende sordi, distratti... Ecco, 6 agosto 1945. Hiroshima. Jacopo tornò proprio in quei giorni, si vede che fu per questo che non appuntai la data, l'Atomica ebbe la capacità di distrarre anche me. [...] Chiudo gli occhi e ascolto soltanto il ricordo di quell'attesa che dilata i secondi, i minuti in un solo suono buio. E non mi accorgo di 'Ntoni che mi viene incontro sulla spiaggia di villa Suvarita. (AG, p. 453. My emphasis)

In the passage above, the narrating voice shifts from Modesta as the narrator of her past to Modesta as the actor of her present, for the two subjects come to coincide in the subject of the expression 'non mi accorgo'. The mimesis of the present in action is overtly stated by the narrator in one of her frequent appeals to the readers:

Sicuramente voi che leggete state pensando che la mia conquista comportava di necessità qualcosa di molto sgradevole: dormire con un essere menomato, se non mostruoso molto brutto. Il fatto è che voi la leggete questa storia, e mi anticipate, mentre io la vivo, la vivo ancora. (AG, p. 99)

Furthermore, the very moment of the end is not pronounced, as the novel finishes on a scene in which Modesta's lover, Marco, asks her to carry on telling her story as she continues to live, in a scene that recalls Shahrazad's affabulatory effect: '- Dormi, Modesta? - No. Pensi? - Sì. - Racconta, Modesta, racconta' (AG, p. 511). The narrator thus creates a present in fieri. To use Sapienza's own words, her narrative reproduces life in the moment of its 
happening, 'la nitidezza del momento stesso in cui la vita-azione sboccia, fiorisce, cresce, cresce ancora, muore' (JG, p. 9).

By voicing the present in action, the narrator of L'arte della gioia seeks to express the primary, constantly renovated encounter between the body and the world. Turning again to Coquet's reflections, 'Il corpo [...] rivela il suo statuto d'esistenza percependo, parlando, operando, tracciando abbozzi di sapere ecc. Il suo privilegio, e anche la sua funzione, è di enunciare per primo il suo rapporto col mondo. ${ }^{41}$ Hence, the constant oscillation between activity and passivity, instincts and rational control, perception and imagination that characterise Modesta, as the narrator reproduces the unstable moment of the present, before the organisation of experience through memory and reflection.

\subsection{A Non-Teleological, Open Narrative}

While telling a story that has already happened belongs to the domain of memory, to narrate a story as it happens belongs to the field of production, in a continuous oscillation between 'return to' and 'return of' the past, diegesis and mimesis. ${ }^{42}$ In L'arte della gioia, the twofold origin of the discourse deeply affects the structure of the novel, since positioning the narrative voice at the end or in the middle of the story entails a different organising principle of the plot. On the one hand, the narrating voice looks back at the past from a mature point of view, to which the significance and consequences of the events are already known. Memory re-presents the past by selecting and organising events into teleologically constructed meaning. According to Brooks, this is the traditional structure of the plot, in which events are held together by their overall meaning in a concluded system:

The beginning presupposes the end, since the concept of an ending is necessary to that of a beginning. The idea of 'adventure' has to do with what is to come, the ad-venire, so that an adventure is a piece of action in which beginnings are chosen by and for ends. The very possibility of meaning plotted through sequence and through time depends on the anticipated structuring force of the ending. [...] We read the incidents of narration as 'promises and annunciations' of final coherence. ${ }^{43}$

On the other hand, the production of experience as it happens does not suffer teleology but only provisional interpretations of ongoing events. Unlike the sense of time developed through memory, the present does not contain in itself the idea of the end and is therefore the 
bearer of an open structure. The character who is still living is not able to select and organise her present on the basis of its following consequences. Hence, many details are provided which do not have any actual influence on the plot, and others are conversely omitted and then instrumentally retrieved following the character's realisation of their initially underestimated importance. The positioning of the narrator in the middle of the story thus accounts for the non-cohesive, wandering narrative structure of L'arte della gioia.

In his analysis of the mechanism of plot, Brooks describes narrative as a repetition of the past aimed at retrospectively organising events whose original production was beyond a subject's control. In this respect, narrative would establish mastery over the past by composing it through memory:

If repetition is mastery, movement from the passive to the active, and if mastery is an assertion of control over what men must in fact submit to - choice, we might say, of an imposed end - we have already a suggestive comment on the grammar of plot, where repetition, taking us back again over the same ground, could have to do with the choice of ends. ${ }^{44}$

In L'arte della gioia, Sapienza challenges this model by miming the present in action. Whereas narrative in the past has to do with the acceptance of a destiny and the assumption of a story that has already happened, Sapienza as we have seen engages with the freedom of the present moment, full of potential and constantly renovated. Instead of achieving mastery and control through repetition of the past, that is, through memory, in L'arte della gioia Sapienza looks for the agency contained in the moment of production. Modesta's movement towards mastery is thus constructed as a movement towards the freedom to experience the present and the presence of the body in action.

\subsection{The Involvement of the Reader: Empathic Narrative Tension}

If the narrator does not organise the narrative material from a space located after the events narrated, how does the plot proceed? How is the narrative tension produced? The focus on the present does not allow the reader to activate a system of expectations. With no guarantee of closure, the elements put in place are unreliable to the reader and thus cannot be read in a chain of memory and anticipation, which following Wolfgang Iser and Brooks normally constitutes the fundamental mechanism of plot. ${ }^{45}$ And yet, the novel succeeds in engaging the 
readers in Modesta's story, throughout over five hundred pages. It does so by establishing a close connection between reader and character, as the adoption of the character's point of view creates an emotive and empathic rather than properly narrative tension. The reader is captured by the hectic sequence of Modesta's feelings, perceptions, reflections and metaphorical descriptions. In Hernández's words, 'the protagonist changes before the reader's eyes - she forges herself - through a constant metamorphosis that produces a sense of vertigo, defined as feverish, frantic or hectic narration' ${ }^{46}$ Instead of developing a deterministic system of expectations, the reader follows Modesta's free movements, participating in her vitality and self-regeneration, the expansion of her experience and her achievement of the freedom to constantly evolve and change.

Similarly to Lettera aperta, character, narrator and readers are represented as sharing the same theatrical space. Modesta is repeatedly defined a 'cantastorie' (AG, p. 8; p. 243) and narration is configured as Modesta's voice reciting her life. The presence of these theatrical modes reinforces the sense of Modesta telling her story as she lives it rather than recollecting events from the past, and involves the reader in a dialogical and empathic structure. Appeals to the readers mark the whole work, beginning from the opening scene in which, as we have seen, the narrator presents the character (Modesta as a child) in front of an audience: 'Ed eccovi me' (AG, p. 5). ${ }^{47}$ On many occasions the narrator involves the readers in the story narrated by introducing to them the voices of other characters: 'Questa voce dolce, non sentite quanto è dolce? È la voce di madre Leonora' (p. 16); 'Questa voce - la sentite?' (p. 420); 'Avete sentito la voce di Beatrice?' (p. 134); 'Ascoltate, anche se non ne avete più voglia' (p. 43). Here Modesta directly addresses the reader as a collective audience present in the same space as hers.

In addition to the appeals to the readers, Sapienza also blends the space of narration and that of the story narrated by virtue of another narrative technique, possibly unique in its kind. Let us consider for example these dialogues between Modesta and Tuzzu and between Modesta and Carmine, where the characters are represented as able to listen to the narrator's thoughts:

Non dovevo lasciarlo andare via, dovevo chiedergli perché - quando lo guardavo prima, e ora che tenevo il suo braccio - mi nasceva dentro quel desiderio di accarezzarmi là dove... - Ma guarda se sono domande da fare! (AG, p. 9) 
Quando è l'alba Carmine se ne va... Nel sonno lo vedo allontanarsi come un'ombra. Come faceva ad apparire e sparire ed essere sempre presente?

- È che mi hai nel cuore, Modesta. (AG, p. 205)

What at first sight appears to be a silent thought belonging to the narrating voice often turns out to be words actually spoken aloud by Modesta, with intensely disorientating effects. These episodes, frequent throughout the novel, break the boundaries between different temporal and spatial domains. This narrative technique also expresses the attraction to oral speech, which characterises Sapienza's works. The dimension of the voice, of pronounced words, exerts an irresistible attraction on language, to the point that the characters are able to 'hear' the narrator's thoughts.

The text is, indeed, populated by voices. As we have seen, drama deeply influences the narrative structure, especially if we consider that more than half of the novel consists of pure dialogues. These take more and more space as the narration proceeds, and in the third and fourth parts they come to occupy almost the totality of narration. The other characters are mainly present on the scene through their voices, of which Sapienza carefully notes the defining qualities. Particularly noticeable in this respect is Modesta's habit of dialoguing with characters who are absent or dead, but whose voices are represented as physical and vibrant, as if they were actually there.

\subsection{The Political Dimension of the Voice}

In the realisation of a present in fieri, as we have seen, the performative, oral dimension of narration plays a crucial role. The voice constitutes the embodied and relational dimension of language, for it is always someone's voice; it links together speaker and listener and roots language into a material exchange. The voice is also, in Cavarero's philosophy, the marker of a person's uniqueness, which resists the universalising feature of disembodied rationality:

Nell'unicità che si fa sentire come voce è un esistente incarnato o, se si vuole, un 'esserci' nella sua radicale finitezza, qui e ora, a farsi sentire. La sfera del vocalico chiama in causa il piano dell'ontologia e lo àncora all'esistenza di esseri singolari che si invocano l'un l'altro, contestualmente. ${ }^{48}$ 
In L'arte della gioia, Sapienza states the contemporaneity of action and narration, in the presence of an audience. Through the qualification of narration as oral speech, she seeks to create with the readers an inter-corporeal and empathic community, rooted in the vocal dimension of communication. Cavarero uses the notion of 'risonanza' to define this type of communication, and Coquet provides a definition that itself resonates with Cavarero's: 'L'intesa intersoggettiva [...] implica l'intercorporeità, un fondamento per così dire musicale: accordarsi alla nota dell'altro che ci sta di fronte e che partecipa alla medesima tonalità fondamentale.' 49

Against abstract thought and its illusion of eternalised time, the voice provides a ground to rethink the category of presence, defined by the co-presence of the interlocutors in a shared, contingent and unstable present:

La presenza di coloro che si guardano 'faccia a faccia', lungi dal funzionare come una qualità eternizzante dell'essere, è garante della contingenza empirica del contesto. [...] Il 'faccia a faccia' evoca un divenire discontinuo, caratterizzato dal presente sempre nuovo degli 'adesso' che incrociano gli sguardi, piuttosto che la dimensione atemporale di un'immobile permanenza. ${ }^{50}$

Differently from the dimension of the voice, abstract and universal rationality ties together individuals by virtue of its laws and erases the bodily and unique existence of each individual. Cavarero writes: 'Gli individui liberi ed eguali, che non hanno niente in comune, trovano finalmente la loro comunità nella razionalità comunicativa di un linguaggio che li lega perché li vincola alle sue norme procedurali. Il linguaggio diventa il legame degli slegati. ${ }^{51}$ The centrality of the voice has, thus, a political dimension, for it grounds communication in the embodied dimension of language and the mutual recognition of singular and unique subjects. As Coquet further argues, 'la comunità linguistica, quella degli uomini, il "contatto con l'altro", presuppone l'intesa [...], un'intesa inscritta sull'asse della physis, e dunque fondata sull'esperienza di una relazione carnale con l'altro, l'empatia.' ${ }^{52}$ His perspective could not express any more cogently the anti-metaphysical and anti-ideological stance represented by Sapienza in L'arte della gioia, and the empathic relationship she seeks to establish with the readers.

\section{Io, Jean Gabin: Wandering Away from the Past}




\subsection{Central Plot and Wandering Thoughts}

After the fictional journey of L'arte della gioia, in Io, Jean Gabin Sapienza goes back to the autobiographical genre, although in a form that is strongly contaminated with fiction. This work, published posthumous in 2010, is set in the same years as Lettera aperta and centres on the child protagonists' endeavour to find some money. As the little girl identifies with French actor Jean Gabin, she experiences her everyday encounters and episodes through a heroic projection, which confers this work a much more ironic and light tone compared to previous texts.

Io, Jean Gabin presents a distinct evolution from Sapienza's previous writings, in terms of narrative structure and relationship between past and present. Compared to the fragmented and centrifugal structure of Lettera aperta, in Io, Jean Gabin a central plot with a chronological development emerges. The child's task to find some money, concentrated in a compact and intelligible unity of space and time, provides the fil rouge of the narration. The central story covers a period of a few days, marked by a succession of meals and sleep. However, in quantitative terms the central and chronological story covers only a limited portion of the text, while several episodes belonging to other periods (some preceding the events of the story, others following it, others situated in a non-specified temporal location), interfere with the linearity and cohesiveness of the central plot. Moreover, the narrator repeatedly interrupts the story with extra-diegetic remarks, usually originated by elements of the plot but neither functional to its development nor strictly constrained by relevance criteria. Sapienza often uses the text as a space to freely develop and link her wandering thoughts, not properly a stream of consciousness but rather the expression of juxtaposed ideas and episodes. Between stream of consciousness and this other discursive structure, which I term 'wandering thoughts', there is no qualitative difference - both actually follow a free association of ideas and images - but rather a difference in intensity, as Sapienza's wandering thinking lacks aim and organisation, but not intelligibility. It is a technique that allows the narrator to address topics she cares about (politics, arts, society etc.), without the constraint of relevance for the plot nor the organisation of such topics into narrative. An analogous narrative mechanism governs many of the dialogues in L'arte della gioia and is present also in Lettera aperta, even though the majority of the text is subject to a much more radical and intense fragmentation.

Overall, Io, Jean Gabin presents similar structural features to previous texts, but manipulation of the narrative discourse is realised on a much less intense scale, so that the disorientating effects produced by Lettera aperta and L'arte della gioia are here mitigated. 
What surely remains unaltered throughout all works, and characterises the later diptych of the prison as well, ${ }^{53}$ is the attention paid by Sapienza to the sensorial dimension of the voice, expression of an embodied and relational approach to language. We hear for example Licia's 'voce delicata' (JG, p. 7), Ivanoe's 'voce cullante' (p. 8), but also his 'dura voce lombarda' (p. 43); the 'curva armoniosa' of Maria’s voice (p. 12); Peppino's 'bella voce fonda' (p. 58); Carlo's 'canti ora lenti ora cullanti, ora alti e argentini come il rincorrersi dei ciottoli smossi dalla risacca' (p. 36) and, when Nica speaks, we hear 'la dolcezza di quelle sillabe scivolanti nel sangue' (p. 44). As in Lettera aperta and L'arte della gioia, the characters are mainly present on the scene through their voices, and the memory of their opinions and teachings is never disjointed from their actual words. For Sapienza, to remember figures from her past always coincides with listening to their voices: "'La miseria è una dannazione senza riscatto!" urla la voce del professor Jsaya all'orecchio della mente. [...] Sento ancora la mia vocina di un tempo belante come una pecora' (JG, p. 56. My emphasis).

The theatrical setting, connected to the prevalence of voices and oral speech, is further reinforced in the characterisation of the readers as a collective audience, to which the narrator addresses her speech. The narrator refers directly to them and to her own act of narrating: 'Avete sentito che voce decisa' (JG, p. 45); 'Già, non ve l'avevo detto' (p. 89); “"Il cinema col tempo diventerà un mezzo formidabile per diffondere cultura e progresso, Goliarda..." queste, oramai l'avete capito, sono frasi di mia madre' (p. 77); ““Allora, carusa, oramai p'aviri l'unuri d'avirti tocca aspettare c'hai la febbre?" [...] È Nunzio, ormai lo conoscete, questo è il bello di parlare a vecchi amici, non c'è bisogno di spiegare troppo, di raccontare tutto da capo' (p. 89). The tendency of Sapienza's works towards theatrical and vocal discourse finds here further confirmation. However, differently from previous texts, in $I o$, Jean Gabin the readers are not invited to play any active role in the narrative discourse. Here, narrator and readers do not actually interact beyond the appeals mentioned above, which then appear more like residual markers of a performance, ultimately inessential to the development of narration. Nonetheless, the readers have become, in Io, Jean Gabin, the narrator's elective company, a sympathetic circle of friends, distinguished from the rest of conformist society which the rebellious protagonist fiercely opposes and despises.

\subsection{Goodbye Childhood}

The deepest difference between Io, Jean Gabin and Sapienza's previous works, however, concerns the narrator's relationship with her past. Indeed, here adult's and child's points of 
view remain clearly distinct, and so do the different spatio-temporal domains where narrator and protagonist reside. Unlike in Lettera aperta, the protagonist's formative process is represented as lying in the past and it no longer involves the narrator, whose present plays a marginal role, as the narrative discourse stays almost constantly focused on the recollection of the past. In terms of linguistic markers of time, past and present tenses alternate, but the alternation happens with much less frequency and overall the past is by far the prevalent tense. The narrator does not dialogue with her past, for the act of recollecting and narrating does not affect her present any longer.

The evolution of Sapienza's works recalls Virginia Woolf's considerations on the role that writing To the Lighthouse (1927) had in her relationship with her own past - and with her mother in particular:

When it was written, I ceased to be obsessed by my mother. I no longer hear her voice; I do not see her. I suppose that I did for myself what psycho-analysts do for their patients. I expressed some very long felt and deeply felt emotion. And in expressing it I explained it and then it laid to rest. ${ }^{54}$

The only occasion in the text where narrator's and characters' voices are actually blended, thus recalling the performative structure and present in fieri of previous works, concerns, quite paradoxically, a passage that states the utter separation of the present from a concluded, already determined and consumed past:

Rassicurandomi con la mano della presenza delle due lire dimenticate nel fondo della tasca, filo via in cerca della mia vita. Ma io l'ho vissuta già la mia vita, penso, almeno tre quattro volte! E per quanto faccia, per quanta volontà, intelligenza, fantasia sprigioni intorno a me per incanalarla e sottometterla al mio volere, mi si delinea davanti quell'unico teorema possibile che è il risultato di mia madre, mio padre, mio zio, i miei fratelli eccetera. Risultato matematico o destino, essa è lì e io ci giro intorno come un asino bendato intorno alla macina. Asino o non asino, con scatto agile salto sul tram che mi porterà lontano. (JG, p. 104)

The passage above is strikingly ambiguous. Not only child's and adult's perspectives conflate and merge in the subject of the expression 'l'ho già vissuta la mia vita'. Its definitive stance is also immediately contradicted by the plurality expressed by the clause 'almeno tre quattro 
volte'. Moreover, whilst the narrator would be doomed to keep re-enacting the same destiny, 'come un asino bendato intorno alla macina', the child protagonist contradicts the circular repetition by affirming her vital action, marked by a linear movement - 'con scatto agile salto sul tram che mi porterà lontano'.

Despite the complex relationship between present and past featured in this passage, in the rest of the work such a relationship is actually quite straightforward. Even though the present is acknowledged as the product of the past, the narrator looks at her past as a closed and stable set of memories. Past and present are finally separated. Narration does not have the creative, assertive and performative power it was bestowed with in Lettera aperta, but functions as a means of recollection of a concluded past. In other words Io, Jean Gabin departs from the formative and performative tension of previous works, for the narrator is not asking the act of remembering and narrating to impact on her present life.

Strengthened by her conquered identity of an anarchic artist, the narrator stands at a safe distance from her past. Originating in the crossing of textual and experiential layers of reality, such an identity is precisely what Sapienza created through her previous 'performances', namely the identity of the artist, the storyteller, at the margins of society (in Sapienza's self-representation) and determined to use such a position as a space enabling personal freedom. It is from this conquered space that the narrator of Io, Jean Gabin tells the story of her own evolution towards it. Therefore the character's formative experience does not proceed in parallel with the narrator's own path of personal reconstruction, as it did in Lettera aperta and Il filo di mezziogiorno, but rather is recollected from a concluded, resolved point of observation. As Pellegrino convincingly argues:

Io, Jean Gabin integra Lettera aperta. [...] Ma chiude il cerchio autobiografico di Goliarda Sapienza. La bambina che qui cammina mano nella mano assieme al suo bandito della casbah per i vicoli tra la gente dell'amato e terribile quartiere non è più la stessa di Lettera aperta, ora è la 'carusa tosta' dell' Arte della gioia. ${ }^{55}$

The difference between Io, Jean Gabin and Sapienza's previous works is connected to her achieved self-positioning in society as an artist, a writer, a storyteller - an identity she was looking for in and through writing. With all the problems annexed to the coincidence of the outcome of the protagonist's formative process with her assumption of the identity of storyteller, such a 'conclusion' is achieved and can provide the starting point of Io, Jean Gabin, this time in concordance with Brook's reflections on the necessity of the end for 
narration to begin. Since she already knows the outcome of her search for identity, narration can depart from the concern with the formative process itself. Indeed, after Io, Jean Gabin Sapienza moves away from the recollection of her childhood to delve into the exploration of her present, and from an endeavour of self-reflection and self-reconstruction to a gaze predominantly focused on outer reality. Her subsequent production, focused on the narrator's present and mainly concerned with other characters, rather than with processes of identity formation, confirms such a shift in her narrative.

Liberated from the effort to master the present by re-traversing the past, the narrator of Io, Jean Gabin constructs a text that constitutes a direct and ironic response to her own search for identity in Lettera aperta and Il filo di mezzogiorno. The parents are mostly ignored, sexuality and male violence largely removed, the oppressive features of the construction of the female role in a patriarchal society are neutralised through the assumption of a male identity, and the duty of social usefulness is discarded in favour of a proudly oppositional anarchism. Nonetheless, beyond the joyful and ironic tone, the fascination and depth of the text - and of Sapienza's literary production more broadly - resides in its ambiguity between achieved evolution and permanence of knots of anxiety, between having put the past 'to rest', and having put it 'between brackets'. At the same time, the narrator appears to be able to detach herself from her past, without re-experiencing its painful and upsetting features. The decision to ignore the troubles involved in the construction of identity (and its future descent into depression and loss of the self) is exhibited as a deliberate act. She cannot change the conditions that constituted her upbringing and led to mental illness, for these belong to a concluded past. She then moves away from that reality and delves into auto-fiction, at the same time pointing at the limits of fiction itself by letting the reality of material oppression and childhood troubles surface. Although closely interconnected with the other works, Io, Jean Gabin also constitutes an unicum, as the text is no longer used as a space where to interact with the past, but a possibility of playful experimentation, as Sapienza creates here a child that she never was. And yet, the apparent fiction of Io, Jean Gabin has behind it, and beneath it, the journey into the past carried out in Lettera aperta and Il filo di mezzogiorno and the desire for self-creation voiced in L'arte della gioia. Treading this fragile line, Io, Jean Gabin constructs its narrative of play of staged identities and bodily desires, recounted by a narrator whose achieved identity coincides with that of an anarchist artist, with its marks of precariousness and marginality.

Both regressive and evolutive tendencies are present in Sapienza's works, and this is one of the many aspects of her narrative that requires the critic to make a choice of emphasis. 
I have focused extensively on the elements of discontinuity, showing how Sapienza's works bear the trace of the healing process she performed through writing, especially as concerns narrative structures. Clearly, another approach, which stresses the persistence of knots of anxiety, repressed rather than resolved issues and return of the same obsessions, is certainly legitimate. ${ }^{56}$ However, overall Sapienza's writings maintain a performative power that exceeds fiction and escapes the re-enactment of the same dynamics. It takes L'arte della gioia, with its exhibited fiction, to make the decisive step. Afterwards, the emergence in Io, Jean Gabin of a - limited and fragile - central narrative, the detachment of the present from the past, the replacement of a generic and overwhelming task (to understand who she is) with a specific and achievable task (to find some money), the side-lining of the parental figures are all elements suitable to be interpreted as markers of an evolution.

\section{Conclusions}

In this article I defined Sapienza's use of narrative as performative, accounting for the evolution of narrative voice and structures in Lettera aperta, L'arte della gioia and Io, Jean Gabin. I focused in particular on the role of the voice in bringing about a corporeal presence and an empathic, intersubjective communication. A conclusive, essential consideration must be made, concerning the qualification of the type of identity and maturation at play in Sapienza's works. To say that through writing Sapienza constructs her own identity and can therefore depart from the investigation of her past does not imply that her formative process as an adult comes to an end. Quite the opposite, the type of identity Sapienza looks for throughout her narrative is rather configured as an open self, sustained by its constantly renovated contact with the vitality of a live body and therefore in continuous evolution and change. Cavarero's words can once again provide useful insights into the type of identity represented by Sapienza:

Da un'identità relazionale ed espositiva, immersa nel flusso dell'esistenza e impadroneggiabile per definizione, non può certo risultare la storia di vita di un sé la cui identità si dia come semplice, come lo sviluppo coerente di un'immutevole sostanza. Tale unità è piuttosto il succedersi nel tempo di una esistenza irripetibile che continuando ad apparire si è fatta storia, ossia è il configurarsi nella temporalità di un ipse. $^{57}$ 
Sapienza's narrative of self-construction, rich in counter-movements and contradictory undercurrents, overall follows a path that takes it from a painful exploration of the past in order to make life possible in the present, to a liberation of desires and imagination in fictional stories. The identity of the anarchist artist, whose cardinal orientating values reside in the auscultation of bodily instincts and the rejection of any form of imposition, allows her to make space for continuous self-renovation, which closely recalls Bono and Fortini's definition of 'romanzo del divenire'. The titles of Sapienza's last published works, with their reference to a formative experience - L'università di Rebibbia - and to the impossibility of a perspective that is rigid and definitive - Le certezze del dubbio - well express the openness of the type of identity proposed by Sapienza.

Sapienza brings to twentieth century Italian literature a remarkably mature and original voice, which incorporates disrupted narratives and identities characterising modernity, as well as post-modern self-awareness and heightened attention to the reader, at the same time going beyond it. Her works do not pursue the direction of intellectual play, lucid dissection of rationality and dissolution of reality into 'un mondo di segni autonomo',58 largely characterising Italian literary modernism and post-modernism. Rather, the tight relationship Sapienza establishes between narrative, agency and bodily presence, in the context of an emancipatory aspiration of freedom, brings about a strong form of desire that is extraneous to the novels of modern crisis and postmodern intellectualism. Sapienza's literary operation rather appears to consonant with the works of other authors, such as Elsa Morante, Dacia Maraini and Fabrizia Ramondino, who represent characters engaged in personal and passionate struggles to become subjects, never disassociating the personal and the political, and whom indeed have started being associated with Sapienza's writings. ${ }^{59}$

In their deconstructive and constructive effort, Sapienza's works are characterised by multifarious, complex and at times contradictory tensions, proper to a performative writing that is itself in search of something, not in possession of an answer or a definitive perspective. Her writing is discontinuous and syncretic, shaped by the effort to represent and elaborate a new subjectivity, ahead of its time in many respects and thus moving, tentatively, in a plurality of directions. As Philippe Pogam notes, through her representation of a radical yearning for freedom Sapienza 'evoca valori universali e futuri'. ${ }^{60}$ Projected towards the future and yet rooted in the desiring matter of the body, Sapienza's narrative offers new ways of thinking the relationship between the self and the world that do not replicate essentialistic and logocentric understanding of the subject, but that are still able to produce agency and emancipation. 
Ultimately, the subject emerging from Sapienza's literary production reflects the relationship that, to quote Maraini's fitting description, she always entertained with the world, a relationship 'da zingara e girovaga' - a joyful, wandering nomad. ${ }^{61}$

\footnotetext{
${ }^{1}$ L'arte della gioia (Turin: Einaudi, 2008). Hereafter AG. The troubled history of its publication is now well documented. See Adele Cambria, 'Goliarda Sapienza e la terribile Arte della gioia', L'Unità, 26 September 2006; María Belén Hernández, 'La fortuna literaria de Goliarda Sapienza', Arena Romanistica, 5 (2009), 14052; Angelo Pellegrino, 'Lunga marcia dell'Arte della gioia', in L'arte della gioia (2008), pp. v-x; Domenico Scarpa, 'Senza alterare niente', in L'arte della gioia (2008), pp. 515-38. An excerpt of a reading of the letters of rejection of L'arte della gioia by various publishers, realised by Pellegrino and Paola Pace, is available on Youtube, $<$ https://www.youtube.com/watch? v=wsctDOZcrWU> [accessed 13 November 2015].

${ }^{2}$ Among these, Io, Jean Gabin (Turin: Einaudi, 2010). Hereafter JG; the poetry collection Ancestrale (Milan: La Vita Felice, 2013) and the plays Tre pièces e soggetti cinematografici (Milan: La Vita Felice, 2014).

${ }^{3}$ For a list of artistic works inspired by Sapienza's life and writings, see the website 'Goliarda Sapienza in Context' <http://goliardasapienza2013.weebly.com/inspired-by.html $>$ [accessed 13 November 2015].

${ }^{4}$ The Art of Joy, trans. by Anne Milano Appel (London: Penguin Books; New York: Farrar, Straus and Giroux, 2013).

${ }^{5}$ Lettera aperta (1967) (Palermo: Sellerio, 1997). Hereafter LA.

${ }^{6}$ For an update overview of the concept of performativity in narratology, see Ute Berns, 'Performativity', in the living handbook of narratology <http://wikis.sub.uni-hamburg.de/lhn/index.php/Performativity $>$ [accessed 13 November 2015].

${ }^{7}$ Adriana Cavarero, A più voci. Filosofia dell'espressione vocale (Milan: Feltrinelli, 2003); Tu che mi guardi, tu che mi racconti (Milan: Feltrinelli, 1997).

${ }^{8}$ Jean Coquet, Le istanze enuncianti. Fenomenologia e semiotica, ed. by Paolo Fabbri, transl. by Elena Nicolini (Milan: Bruno Mondadori, 2008); Mark Turner, The Literary Mind (Oxford: Oxford University Press, 1996); Peter Brooks, Reading for the Plot: Design and Intention in Narrative (London: Harvard University Press, 1992).

${ }^{9}$ Paola Bono and Laura Fortini, 'Introduzione', in P. Bono and L. Fortini, eds., Il romanzo del divenire. Un Bildungsroman delle donne? (Rome: Iacobelli, 2007), pp. 7-13. Mikhail Bakhtin, 'The Bildungsroman and its Significance in the History of Realism (Toward a Historical Typology of the Novel)', in Speech Genres and Other Late Essays, ed. by Caryl Emerson and Michael Holquist, transl. by Vern W. McGee (Austin: University of Texas Press, 1986), pp. 10-59.

${ }^{10}$ Anna Langiano, 'Lettera aperta: il dovere di tornare', in Giovanna Providenti, ed., 'Quel sogno d'essere' di Goliarda Sapienza. Percorsi critici su una delle maggiori autrici del Novecento italiano (Rome: Aracne, 2012), pp. 131-47 (p. 143).

${ }^{11}$ For an exploration of the mechanisms of analogy and fragmentation in Lettera aperta, see: Giuliana Ortu, 'Cosa vedono gli occhi di quella bambina. Lettera aperta', in Monica Farnetti, ed., Appassionata Sapienza (Milan: La Tartaruga, 2012), pp. 148-79; Mariagiovanna Andrigo, 'L'evoluzione autobiografica di Goliarda Sapienza. Stile e contenuti', in Quel sogno d'essere, pp. 117-30; Langiano.

${ }^{12}$ Langiano, p. 138.

${ }^{13}$ Ortu, p. 151. My emphasis.

${ }^{14}$ Andrigo, p. 124; Anna Carta, 'Finestre, porte, luoghi reali e spazi immaginari nell'opera di Goliarda

Sapienza', in Quel sogno d'essere, pp. 261-76 (p. 267).

${ }^{15}$ Cavarero, Tu che mi guardi, p. 91.

${ }^{16}$ Ibid. p. 129.

${ }^{17}$ LA, pp. 85-93.

${ }^{18}$ Laurence Sterne, The Life and Opinions of Tristram Shandy, Gentleman (1760). In this respect, Lettera aperta (and the same is true of all Sapienza's aubiographical works) also reconnects with the nineteenth century Italian tradition of anti-novelistic, auto-fictional writings, such as Carlo Dossi's L'altrieri: nero su bianco (1868) and Vita di Alberto Pisani (1870), and Ugo Foscolo's unfinished autobiographical novel Sesto tomo dell'io (1799$1800 ; 1991)$.

${ }^{19} \mathrm{LA}$, pp. 36-7. The warning to the reader about a chapter that can be skipped has another important precedent in Alessandro Manzoni's introduction of the digression on Cardinal Federigo Borromeo in Chapter XII of $I$ promessi sposi (1840) (Milan: Garzanti, 1992).

${ }^{20}$ Turner, pp. 75-6.

${ }^{21}$ Ibid. p. 76.
} 
22 Langiano, p. 133.

${ }^{23}$ Natalie Castagné, 'Archeologia di Modesta', in Quel sogno d'essere, pp. 81-91 (p. 82).

${ }^{24}$ Cavarero, A più voci, p. 185.

${ }^{25}$ Ibid. p. 149.

${ }^{26}$ Coquet, p. 68.

${ }^{27}$ Cavarero, Tu che mi guardi, p. 163.

${ }^{28}$ Ibid. p. 24.

${ }^{29}$ Sibilla Aleramo, Una donna (1906).

${ }^{30}$ Cavarero, Tu che mi guardi, p. 163.

${ }^{31}$ Carta, p. 275.

${ }^{32}$ Cavarero, Tu che mi guardi, p. 49.

${ }^{33}$ See Turner, p. 15.

${ }^{34}$ Margaret Somers, 'The Narrative Constitution of Identity. A Relational and Network Approach', in Theory and Society, 5, 23 (October 1994) 605-49 (pp. 606-7).

${ }^{35}$ Le certezze del dubbio (1987) (Milan: Rizzoli, 2007).

${ }^{36}$ Charlotte Ross, 'Identità di genere e sessualità nelle opere di Goliarda Sapienza: finzioni necessariamente queer', in Quel sogno d'essere, pp. 223-42 (p. 224).

${ }^{37}$ Maria Arena, 'Il filo di mezzogiorno. Morte e rinascita attraverso la scrittura', in Quel sogno d'essere, pp. 14956 (p. 151).

${ }^{38}$ Il filo di mezzogiorno (1969) (Milan: La Tartaruga, 2003). On therapy and writing in Il filo di mezzogiorno see Emma Bond, 'Zeno's Unstable Legacy: Case-Writing and the Logic of Transference in Giuseppe Berto and Goliarda Sapienza', in Italo Svevo and his Legacy for the Third Millenium: Contexts and Influences, ed. by Giuseppe Stellardi and Emanuela Tandello Cooper (Leicester: Troubador, 2014), pp. 101-13.

${ }^{39}$ Natalia Ginzburg, 'Avvertenza', in Lessico famigliare (1963) (Turin: Einaudi, 1992).

${ }^{40}$ Monica Farnetti, Il centro della cattedrale. I ricordi d'infanzia nella scrittura femminile (Mantova: Tre Lune Edizioni, 2002). For a comprehensive perspective on recent criticism and theory on autobiography, see Linda Anderson, Autobiography (London: Routledge, 2001).

${ }^{41}$ Coquet, pp. 24-5.

42 Brooks, p. 98.

${ }^{43}$ Brooks, p. 93. On the function of the end in the structuring of narratives, see also Frank Kermode, The Sense of an Ending: Studies in the Theory of Fiction: with a New Epilogue, new edn (Oxford: Oxford University Press, 2000).

${ }^{44}$ Brooks, p. 98.

${ }^{45}$ Wolfgang Iser, The Act of Reading: A Theory of Aesthetic Response (London: Routledge \& Kegan Paul, 1978).

${ }^{46}$ Hernández, p. 8. Translation is mine.

${ }^{47}$ Unfortunately, in the English translation - 'I'm four or five years old' - the theatrical exposition of the character to the readers is lost.

${ }^{48}$ Cavarero, A più voci, p. 189.

${ }^{49}$ Coquet, p. 68.

${ }^{50}$ Cavarero, A più voci, p. 193.

${ }^{51}$ Ibid. p. 205. Of course, a completely different way to look at the voice is possible, for example and most notably in Derrida's theory, according to whom the voice, with its illusion of presence, represents an ally of metaphysics, against the différant feature of writing. However, in Cavarero's view, the voice is not opposed primarily to writing, but to the a-temporal and video-centric feature of metaphysics. Cavarero's and Derrida's perspectives do not seem to be in a relationship of symmetrical opposition, but rather express incommensurable positions, for they attach very different roles to the voice within their overall systems. The relationship between the two approaches would deserve specific investigation, but for purposes of the present discourse what matters is that in Sapienza's works the voice plays an anti-metaphysical and anti-logocentric role, reinstating the body and its contingent and relational presence. See Jacques Derrida, Speech and Phenomena, and Other Essays on Husserl's Theory of Signs, trans. by. David B. Allison (Evanston: Northwestern University Press, 1973); Of Grammatology, corrected ed., trans. by Gayatri Chakravorty Spivak (Baltimore: Johns Hopkins University Press, 1997).

52 Coquet, p. 70.

${ }^{53}$ L'università di Rebibbia (Milan: Rizzoli, 1983).

${ }^{54}$ Virginia Woolf, Moments of Being, ed. by Jeanne Schulkind (London: Chatto \& Windus for Sussex University Press, 1986), p. 81.

55 Pellegrino, 'Postfazione', in JG, p. 123.

${ }^{56}$ For example, Bond's analysis of Il filo di mezzogiorno pursues this direction.

${ }^{57}$ Cavarero, Tu che mi guardi, p. 96.

${ }^{58}$ Alberto Asor Rosa, Stile Calvino (Turin: Einaudi, 2001), p. 138. 
${ }^{59}$ On a parallel between Maraini and Sapienza's works, focused on the theme of prison, see Maria Morelli, "L'acqua in gabbia": the Heterotopic Space of the (Female) Prison in Goliarda Sapienza and Dacia Maraini's Narratives', in Alberica Bazzoni, Emma Bond \& Katrin Wehling-Giorgi, eds., Goliarda Sapienza in Context. Intertextual Relationships with Italian and European Culture (New Jersey: Fairleigh Dickinson University Press, 2016), pp. 199-214. On Sapienza and Ramondino, see Laura Ferro, 'Changing Recollections: Goliarda Sapienza and Fabrizia Ramondino Writing and Rewriting Childhood', in Goliarda Sapienza in Context, pp. 18198; On Sapienza and Morante, see Alberica Bazzoni, 'Agency and History in Sapienza's L'arte della gioia and Morante's La storia', in Goliarda Sapienza in Context, pp. 147-61.

${ }^{60}$ Philippe Pogam, translated by Michele Zaffarano, in Cythère-Critique <http://www.cytherecritique.com/PRESSE/pressesept05.html> [Last Accessed 11 November 2016].

${ }^{61}$ Dacia Maraini, 'Ricordo di Goliarda Sapienza', in LA, pp. 9-11 (p. 11). 